\title{
Assessment of hydrologic impact of climate change on Ord River catchment of Western Australia for water resources planning: A multi-model ensemble approach
}

\author{
$\underline{\text { S.A. Islam }}^{\text {a }}$, M. Bari ${ }^{\text {b }}$, and A.H.M.F. Anwar ${ }^{\text {a }}$ \\ ${ }^{a}$ Department of Civil Engineering, School of Civil and Mechanical Engineering, Curtin University, Western \\ Australia \\ ${ }^{b}$ Extended Hydrological Prediction, Climate and Water Division, Bureau of Meteorology, Western Australia \\ Email:syed.a.islam@postgrad.curtin.edu.au
}

\begin{abstract}
Climate change, a harsh reality of modern civilization, has significant impact on water resources. General Circulation Models (GCMs) can predict long term impact of climate change at large or continental scale with some degree of accuracy. But the locus of interest of hydrologist and decision makers is to evaluate probable impact of climate change at local scale, individual catchment, and or at basin scale. In Australia, limited study has been done to find the impact of climate change on water resources at local scale.

In this study, hydrological impact of climate change on the Ord River catchment is assessed using modelled runoff from rainfall projections for two Intergovernmental Panel on Climate Change (IPCC) emission scenarios A2 and B1 for the period of 2046-2065 and 2081-2100. To address uncertainties due to differences in GCMs, a multi-model ensemble approach (with 11 GCMs data) has been adopted. For downscaling GCM data to a $5 \mathrm{~km}$ resolution (compatible with catchment modelling), Bureau of Meteorology Statistical Downscaling Model (BoM-SDM) is used. The Land Use Change Incorporated Catchment (LUCICAT) hydrologic model is applied to simulate future rainfall and runoff using downscaled rainfall. The model is calibrated with recently developed $5 \mathrm{~km}$ grid rainfall produced by the Bureau of Meteorology, Australia .

The model calibrated well at all gauging stations of the Ord River catchment. Observed mean annual runoff and modelled mean annual runoff at all six gauging stations are within $\pm 3 \%$. Observed rainfall and runoff data suggest that rainfall and runoff has an increasing trend in the northern part of Western Australia in recent times. Findings suggest that the recent rainfall pattern may continue for mid this century (2046-2065) for both scenarios A2 and B1 with a slight increase of mean annual runoff by around $1.77 \%$ for scenario A2 and $1.06 \%$ decrease for scenarios B1,compared to hind cast mean annual runoff for the period 1981-2000. But during last part of this century (2081-2100), there might be a decrease of runoff for the Ord River catchment of around $12 \%$ for scenario A2, and around $7 \%$ for B1 compared to hind cast runoff for period 1981-2000. Out of $11 \mathrm{GCMs}$, eight have shown reasonably consistent results compared to mean annual runoff modelled form observed rainfall and hind cast mean annual runoff for period 1981-2000. Significant variation in terms of runoff projection has also been observed among the GCMs, indicating considerable uncertainty in applying downscaled GCM data for rainfall and runoff projection.
\end{abstract}

Keywords: Ord River catchment, LUCICAT model, rainfall and runoff, hydrologic impact, climate change 


\section{INTRODUCTION}

Australia is a dry continent with a highly variable climate, limited water resources and is characterized by variable rainfall and river flow regime. With increasing population and economic activities, demand for water is increasing day by day which is creating more pressure on inland water system (Beeton et al., 2006). Though, General Circulation Model (GCM) can simulate mean features of climate at large or continental scale, hydrologist, policy makers, and water resources managers need rainfall and runoff simulation at catchment level for water resources planning. Rainfall and runoff simulation at catchment level could be done through generating rainfall data through downscaling GCM variable. Again, there are many GCMs all over the world and their simulation for climate variables vary considerably for a particular area in a particular time. Thus, considerable uncertainty involves in projecting future runoff at catchment level depending on selection of GCM(s). To address uncertainty, in this study, a multi-model ensemble approach has been adopted for projecting rainfall runoff for the Ord River catchment of Western Australia. The catchment is very well known for the fertile plains of lower reaches of the Ord River, the Ord Irrigation Scheme, hydroelectric power station and Lake Argyle, the largest manmade lake in Australia.

In the south-west of Western Australia, rainfall has a decreasing trend since 1970s (IOCI, 2002). In contrast, rainfall has an increasing trend in the Ord River catchment in recent times. Now, the question is will this rainfall trend continue for the future? Answer to this question is important for sustainability of the agricultural industry, hydropower generation, economic activities, ecology, environment and water resources planning in the northern part of Western Australia or regional water resources planning in a broader context. A study have been conducted by Bari and Rodgers (2006) for generating a 98-year (1905-2002) daily runoff series for the catchment Limited study has been carried out for projecting future rainfall runoff of the Ord River catchment. Under CSIRO Northern Australia Sustainable Yields Project, future rainfall and runoff of the Ord-Bonaparte region has been projected for a future Scenario C (climate conditions estimated for 2030 compared to $\sim 1990$ conditions) (CSIRO,2009). In this study, we have projected rainfall runoff of the Ord River catchment for $21^{\text {st }}$ century, 1946-2065 and 1981-2100 for two IPCC emission scenarios, A2 and B1.

\section{THE ORD RIVER CATCHMENT}

With an area of $53000 \mathrm{~km}^{2}$, the Ord River catchment is a dry land ephemeral river system located in the Kimberly region of Western Australia. It extends into Northern Territory in the east and to the junction of the Dunham and Ord along north (Figure 1). The climate can be described as a hot rangeland climate and rainfall varies considerably from north to south. The average annual rainfall in the north is around $780 \mathrm{~mm}$ while it is around $450 \mathrm{~mm}$ in the south with most of the rainfall (around 90\%) occurring from November to April. Pan evaporation of the catchment ranges from 2800 to $3400 \mathrm{~mm} /$ year from north to south. Northern rivers are fairly short, flow only during the short wet season but carry half (about 200,000 gigalitres (GL)) of Australia's total yearly stream flow (CSIRO, 2009). Approximately 46000 $\mathrm{km}^{2}$ catchment area is feeding into Lake Argyle with mean annual inflow (19702002) of $5740 \mathrm{GL}$, though the flow varies

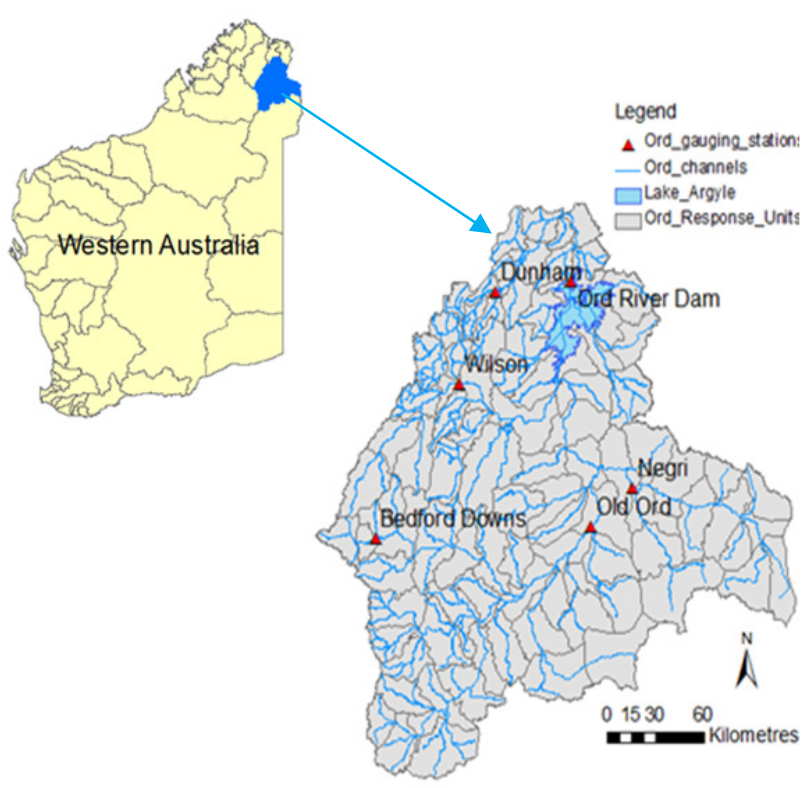

Figure 1. Location of the Ord River catchment and map of the catchment showing Response Units, stream network, gauging stations and Lake Argyle.. significantly between years (350 to 19400

GL). Thus, Ord River is one of the fastest flowing rivers in Australia. Harnessing of the water of the Ord River has transformed the semi-desert cattle county to a year round agricultural area. The first stage of the Ord Irrigation Scheme has started with the construction of the Kununurra Diversion Dam across the Ord River which was completed in 1963. The construction of the Ord River dam in the Carr Boyd Ranges was completed in 1972 forming Lake Argyle. 


\section{DATA AND METHODS}

The study can be divided into five components (Figure 2): (1) preparation of input files for the LUCICAT, calibration of the model with observed runoff at different gauging stations, (3) Preparation of GCM rainfall data for Scenario A2 and B1 of different time periods for input into the calibrated model, (4) run the model for projection of rainfall and runoff for the future as well as historical period for different climate scenario and (5) interpretation of the model output.

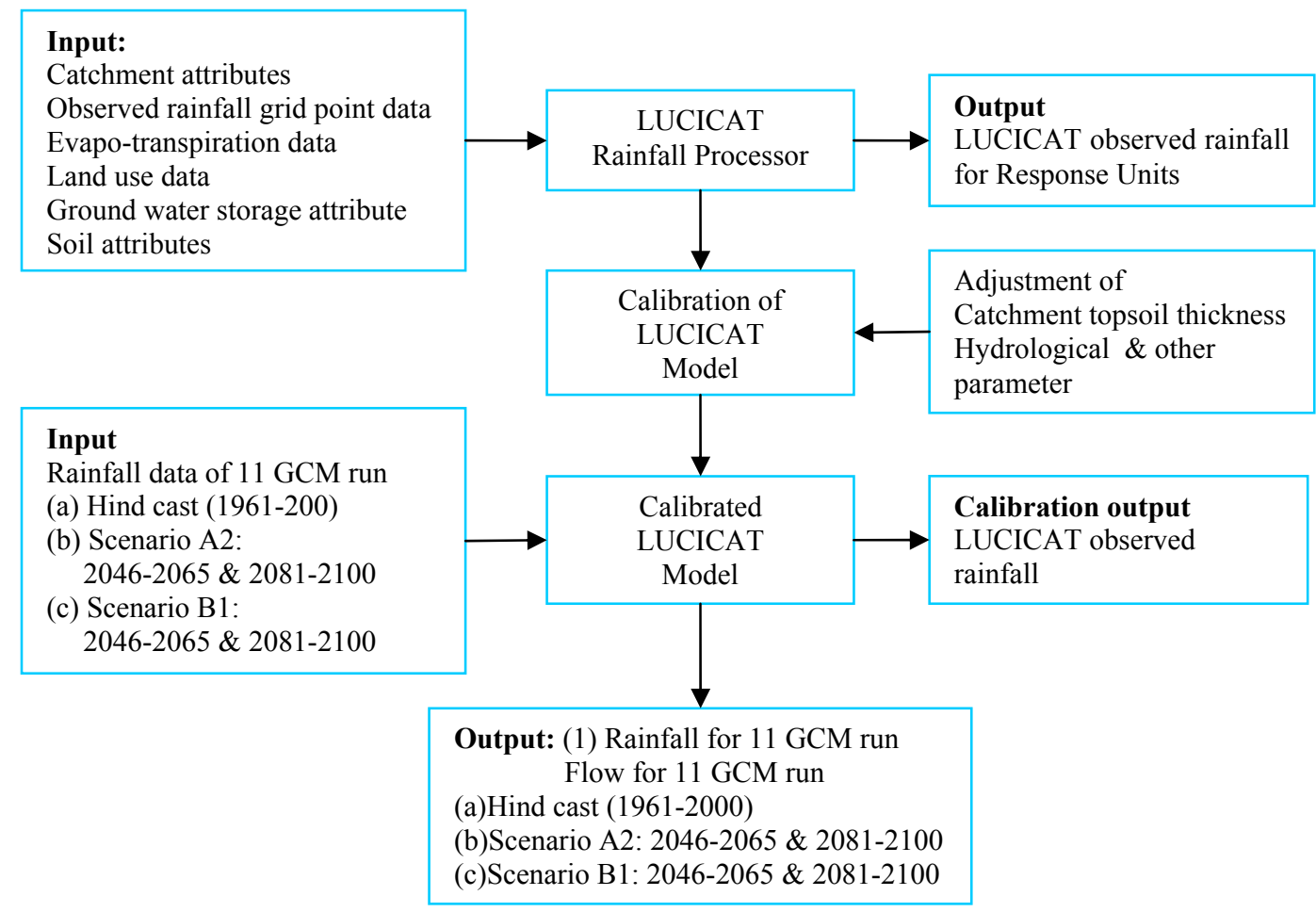

Figure 2. Conceptual diagram of the LUCICAT modelling process with climate change scenarios

\subsection{The LUCICAT Hydrological Model}

The LUCICAT is a distributed lumped conceptual hydrological model successfully used for modelling Western Australian Hydrology (Bari and Smettem, 2006). It models a large catchment by dividing into small Response Units for taking into account varying spatial distribution of rainfall, pan evaporation, land use, catchment attributes and other parameters. The RUs are fundamental 'building-block' of the model which is represented by a simple hill slope and catchment attributes are put into the building block model (Bari and Smettem, 2006). Each of the building-block consists of three main components: (i) a two-layer unsaturated soil module (dry, wet and subsurface stores), (ii) a saturated subsurface ground water module and (iii) a transient stream zone module (Charles et al., 2007). The variable infiltration capacity (VIC) model (Wood et al., 1992) represents the upper zone unsaturated store with a simple probability distribution function of the soil moisture capacity. Groundwater induced saturated areas along the stream zone is delineated by the transient stream zone. Water movement in the unsaturated zone is represented by the fluxes between the top layer dry and wet stores. The ground water fluxes towards the stream zone are governed by the ground water storage. Flow generated from each of the RU is routed downstream following Muskingum-Cunge routing scheme (Miller \& Cunge, 1975). The runoff generated within the catchment flows through a channel network following the principles of open channel flow hydraulics. The model can simulate daily runoff at any designated node and it runs on a daily time step within the LUCICAT Live framework (Bari et al., 2009).

\subsection{General Circulation Models and Climate Change Scenarios}

Based on available literature and the IPCC Fourth Assessment Report (IPCC, 2007), 11 GCMs are selected in this study for producing rainfall and runoff scenarios which is summarized in Table 2 . These models are selected based on the consistent simulation runs in terms of the future simulation period (Christensen \& Lettenmaier, 2007) and suitability for Australian climate. These 11 models run for at least the period 1981- 
Islam et al., Assessment of hydrologic impact of climate change on Ord River catchment

2100 for the emission scenarios, A2 and B1, used in this study. As the 11 models covers major climate modelling centres, this study could be considered as a generalized approach for generating rainfall and runoff scenarios for the Ord River catchment.

Table 1. General Circulation Models used in this study to produce rainfall and runoff scenarios

\begin{tabular}{lll}
\hline Abbreviation & \multicolumn{1}{c}{ Modelling Group/Country } & IPCC Model ID \\
\hline CSIRO2 & CSIRO Atmospheric Research, Australia & CSIRO/CSIRO2 \\
CSIRO & CSIRO Atmospheric Research, Australia & CSIRO-MK3.0 \\
GFDL & Geophysical Fluid Dynamics Laboratory, USA & GFDL1 \\
GFDL & Geophysical Fluid Dynamics Laboratory, USA & GFDL2 \\
GISS & Goddard Institute for Space Studies, USA & GISS-ER \\
CNRM & Centre National de Recherches Météorologiques, France & CNRM-CM3 \\
IPSL & Institute Pierre Simon Laplace, France & IPSL-CM4 \\
MIROC & Centre for Climate Systems Research, Japan & MIROC3.2 \\
MPI & Max Planck Institute for Meteorology, Germany & ECHAM5/MPI-OM \\
MRI & Meteorological Research Institute, Japan & MRI-CGCM2.3.2 \\
CCM & Canadian Climate Centre, Canada & CCM \\
\hline
\end{tabular}

\subsection{Data, Downscaling Rainfall and Modelling Runoff for the Ord River Catchment}

The LUCICAT model takes input of catchment attributes through ArcGIS shape files. For this, shape files are produced with catchment attributes, stream network and nodes. Before that the Digital Elevation Model (DEM) of the catchment was processed with ArcHydro tools to divide it into 93 Response Units and to generate stream network and nodes. Land use history and pan evaporation data of the catchment are prepared for input into LUCICAT. Historical $5 \mathrm{~km}$ grid rainfall data for the period 1960-2009 is collected from the Bureau of Meteorology (BoM), Australia and processed for input into the model. Then the model is calibrated for the period 1960-2002 at six gauging stations within the catchment with available observed runoff data. The $11 \mathrm{GCMs}$ run downscaled rainfall data for scenario A2 and B1 for three different periods (1981-2000, 2046-2065 and 2081-2100) are collected from the BoM and applied into calibrated model to produce future rainfall runoff scenario for the catchment. For downscaling of the GCMs rainfall data, state of the art Bureau of Meteorology Statistical Downscaling Model (BoM-SDM) is used which (BoM-SDM) works on analogue approach shown by Timbal et al.(2009). The downscaled rainfall data is processed for input into the calibrated LUCICAT model.

\section{CALIBRATION}
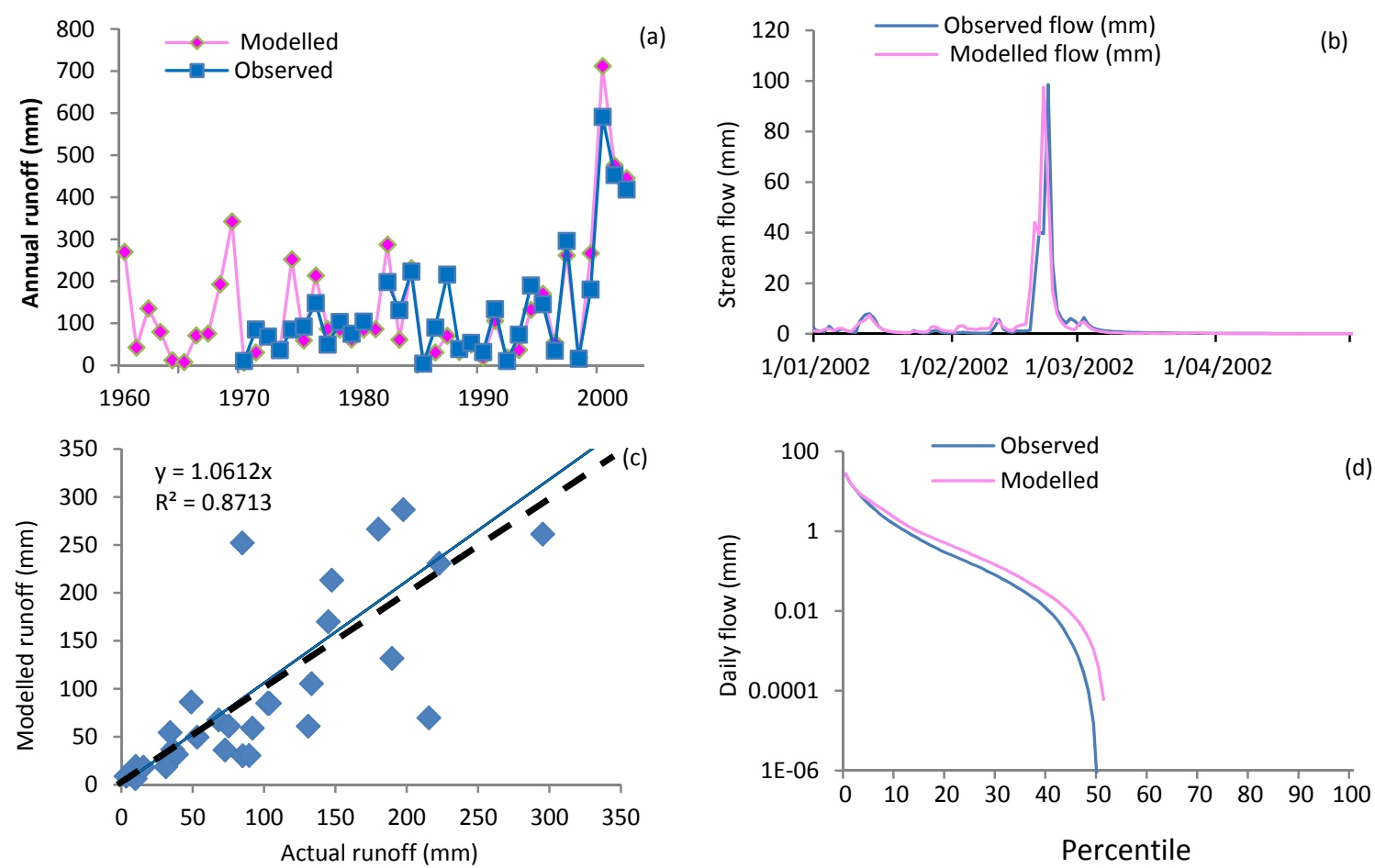

Figure 3. (a) Plot of annual observed and modelled runoff, (b) Daily observed and modelled runoff, (c) plot of observed and modelled annual flow, and (d) flow duration curve at Dunham Gauging station. 
The model is calibrated for the period 1960 to 2002 at all six gauging stations of the Ord River Catchment using $5 \mathrm{~km}$ grid rainfall produced by the Bureau of Meteorology (Jones et al., 2009). Model calibration has been conducted through a trial and error method against a defined standard set of criteria to measure how closely the modelled daily runoff agrees with observed runoff. A single set of parameters is used for the entire catchment. Out of six gauging stations, calibration result of Dunham gauging station is presented here (Figure 3). Results indicate that the model is calibrated well at all gauging stations in terms of annual flow, daily flow and flow duration. At all gauging stations observed and simulated annual average flow are within $\pm 3 \%$. Due to increase of rainfall in recent times in Northern part of Western Australia, there is significant increase in annual runoff observed in the catchment and model performed well in simulating the response to this change. In addition to six gauging station, monthly lake water balance has been checked for Lake Argyle and results of observed and modelled runoff have found been consistent for the calibration period.

\section{PROJECTION OF RAINFALL AND FUTURE RUNOFF}

We have considered 4615 grid point for rainfall data spaced in a $5 \mathrm{~km}$ grid within and adjacent to the catchment for calibration and rainfall projection. After calibration, we have used downscaled daily rainfall data of 11 GCM (Table 2) for the period 1961-2000, 2046-2065 and 2081-2100. Seasonal bias correction factor has been applied to the downscaled grid point rainfall data. Rainfall and other files (pan evaporation, land use etc.) has been prepared in a format suitable for input into LUCICAT model. With the run of the
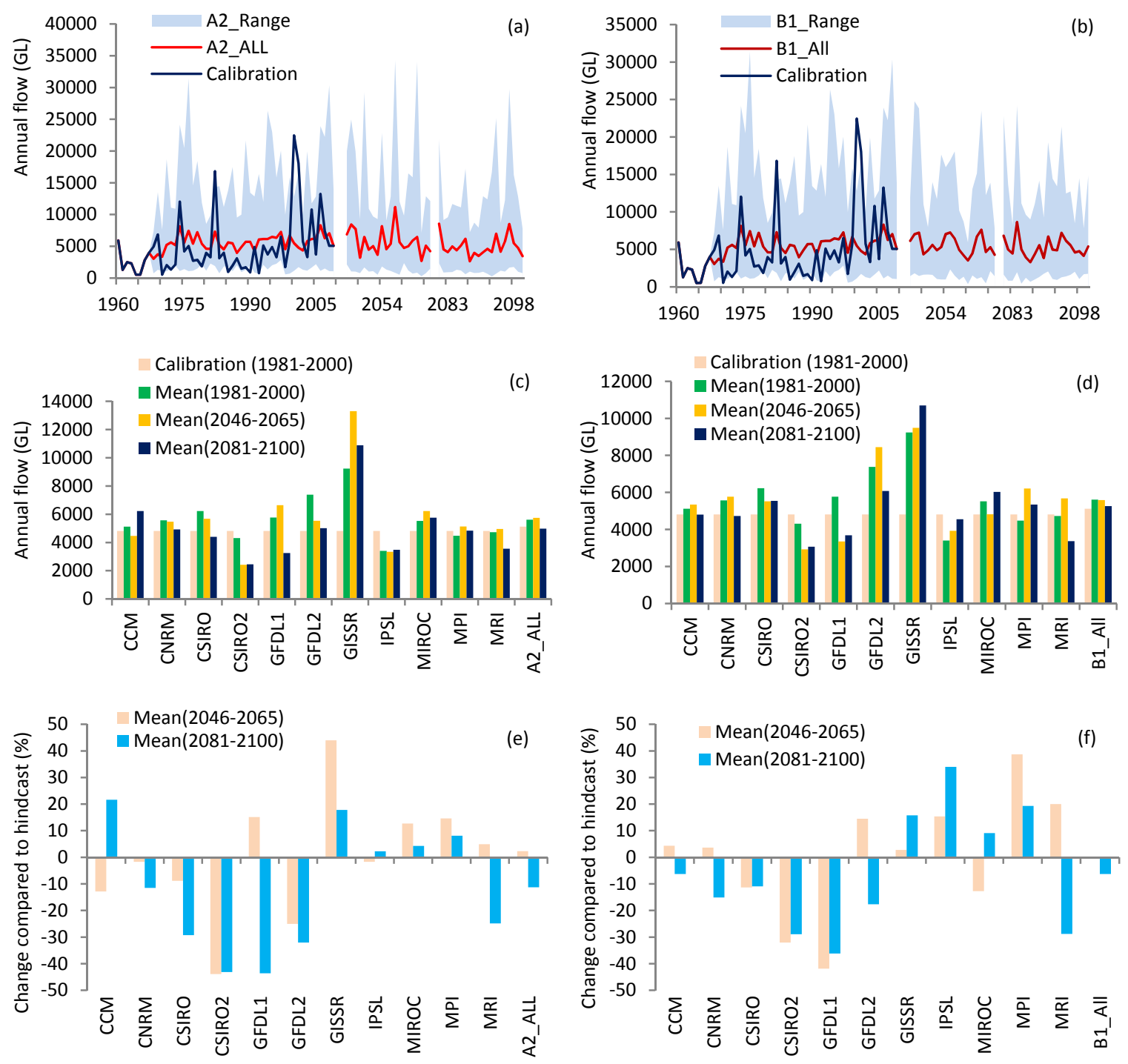

Figure 4. (a) Ensemble mean runoff projection from eleven GCM run for Scenario A2, (b) scenario B1. (c) and (d) Mean annual runoff for eleven GCM for different period for Scenario A2 and B1 respectively. (e) and (f) Percentage variation of individual GCM compared with hind cast runoff for scenario A2 and B1. 
model, rainfall and runoff has been available at designated nodes. We have compared ensemble mean runoff (A2_ALL and B1_ALL) of the 11 GCMs with modelled runoff (calibration) from observed rainfall for 1960 to 2009 (Figure $\overline{4}$. (a) and (b)) and presented maximum and minimum runoff range (A2 Range and B1_Range) combining all the GCM output for both scenario A2 and B1. Figure 4 (a) and (b) also presents ensemble mean runoff, maximum and minimum runoff for 2046-2065 and 2081-2100, for both the scenarios. We have compared mean annual runoff of individual GCM for different time period 1981-2000, 2046-2065 and 2081-2100 with modelled runoff for the period 1981-2000 to draw a picture of runoff change throughout this century for the catchment.

Ensemble mean projection of runoff for the Ord River catchment shows that similar pattern of runoff may continue for mid this century and decrease in the end of this century. Pattern of runoff for both scenario A2 and B1 looks similar with slight difference in time scale for mid and end of this century. Runoff projections from individual GCM suggest that eight GCMs out of eleven have performed well in depicting mean annual runoff from observed rainfall (1981-2000). GFDL2, GISSR and IPSL have shown considerable variations with modelled mean annual runoff from observed rainfall and mean annual runoff for hind cast (Figure 4. (c) and (d)). For projection of runoff for middle and end of this century, different GCMs have shown considerable variations in runoff changes (Figure 4. (e) and (f)). The variation is also significant for different time periods. For example, GFDL1 has shown increase of mean annual runoff compared to mean of hind cast for mid this century but considerable decrease of runoff at end of this century (Figure 4. (c)). Large deviations in runoff changes have also been observed for different climate change scenarios, A2 and B1 for middle and end of this century.

During mid this century, mean annual runoff would be different with $1.77 \%$ increase for scenario A2 and $1.06 \%$ decrease for scenario B1 compared to mean annual runoff for hind cast for period 1981-2000 at Ord River Dam. But runoff may decrease significantly by the end of this century (2081-2100) with ensemble mean annual runoff decrease of around $12 \%$ for scenario A2 and $7 \%$ for scenario B1 compared to the mean annual runoff for hind cast for 1981-2000 (Table 2). Overall, mean annual flow modelled from the observed rainfall for the catchment for 1981-2000 is $5418 \mathrm{GL}$. The mean annual runoff (5386 GL) for hind cast for 1981-2000 is around 17 percent higher than historical mean annual flow (4611 GL) at Ord River Dam. This indicates upward bias of rainfall projection of the GCMs downscaled rainfall data which could be adjusted through application of some correction factors. Then the corrected rainfall might be used for future runoff projection. This may lead to a reduction of runoff for mid this century and further reduction by the end of this century compared to the results presented in this study (Table 2). Projected runoff changes (Table 2) at different gauging stations indicate that spatial and temporal distribution of rainfall runoff change within the catchment may vary considerably in the future.

Table 2. Historical and hind cast stream flow for Ord River catchment with ensemble mean from 11 GCM.

\begin{tabular}{|c|c|c|c|c|c|c|c|}
\hline \multirow{2}{*}{ Gauging Stations } & \multirow{2}{*}{$\begin{array}{c}\text { Mean Annual Flow (GL) } \\
\text { and \% Change to Hind cast }\end{array}$} & \multirow{2}{*}{$\begin{array}{c}\text { Historical } \\
1981-2000 \\
\text { (Calibration) }\end{array}$} & \multirow{2}{*}{$\begin{array}{l}\text { Hind cast } \\
1981-2000\end{array}$} & \multicolumn{2}{|c|}{ 2046-2065 } & \multicolumn{2}{|c|}{$2081-2100$} \\
\hline & & & & A2 & B1 & A2 & B1 \\
\hline \multirow{2}{*}{ Ord River Dam } & Mean Annual Runoff & 4611 & 5386 & 5481 & 5329 & 4740 & 5008 \\
\hline & $\%$ Change to Hind cast & & & 1.77 & -1.06 & -11.99 & -7.02 \\
\hline \multirow{2}{*}{ Dunham } & Mean Annual Runoff & 228 & 400 & 398 & 415 & 464 & 388 \\
\hline & $\%$ Change to Hind cast & & & -0.56 & 3.81 & -9.05 & -3.12 \\
\hline \multirow{2}{*}{ Bedford Downs } & Mean Annual Runoff & 93 & 99 & 101 & 95 & 89 & 89 \\
\hline & $\%$ Change to Hind cast & & & 2.43 & -3.81 & -9.95 & -9.28 \\
\hline \multirow{2}{*}{ Old Ord } & Mean Annual Runoff & 2224 & 2204 & 2284 & 2148 & 1909 & 1993 \\
\hline & $\%$ Change to Hind cast & & & 3.61 & -2.55 & -13.35 & -9.61 \\
\hline \multirow{2}{*}{ Negri } & Mean Annual Runoff & 479 & 483 & 550 & 510 & 429 & 480 \\
\hline & $\%$ Change to Hind cast & & & 13.75 & 5.38 & -11.36 & -0.76 \\
\hline \multirow[t]{2}{*}{ Wilson } & Mean Annual Runoff & 345 & 471 & 453 & 458 & 412 & 428 \\
\hline & $\%$ Change to Hind cast & & & -3.76 & -2.76 & -12.47 & -9.16 \\
\hline
\end{tabular}

\section{SUMMARY AND CONCLUSION}

Located in the Kimberly region, flow from the Ord River catchment to Lake Argyle is important for sustainability of the Ord Irrigation Scheme, hydropower generation, economic activities and environment. For assessing climate change impact on water resources of the catchment, LUCICAT hydrologic model has been calibrated at six different gauging stations including reservoir water balance. Calibration results have shown good agreement at all gauging stations with mean difference of observed and simulated annual runoff within $\pm 3 \%$. Assessment of sensitivity of water resources of the Ord River catchment to climate change has been carried out using downscaled rainfall data of 11 GCMs for two IPCC emission scenarios, A2 and B1. Along with maximum and minimum range of runoff, ensemble mean of the $11 \mathrm{GCMs}$ runoff projections has 
been taken to address uncertainty. Hence, this study is able to evaluate implications of climate change on water resources of the catchment with the range of possible consequences as represented by major climate models and emission scenarios. Overall modelled mean annual runoff from the catchment for the period 1981 to 2000 has been found 5418 GL. Ensemble mean annual runoff projection (hind cast mean annual runoff $5386 \mathrm{GL}$ ) for the period 1981-2000 at Ord River Dam which is around $17 \%$ higher than historical mean (4611 GL) of similar time. Projected runoff for mid this century (2046-2065), compared to that of the hind cast runoff for period 1981-2000, is different with $1.77 \%$ increase for scenario A2 and $1.06 \%$ decrease for scenario B1 at Ord River Dam. During late this century (2081-2100), mean annual runoff may decrease for the catchment compared to hind cast runoff (1981-2000) by 12\% for scenario A2 and 7\% for scenario B1. Spatio-temporal distribution of rainfall runoff (Table 2) for the catchment may also vary considerably for this century. Runoff projections vary considerably among the GCMs for different time period (2046-2065 and 2081-2100) and IPCC scenarios, A2 and B1.

\section{REFERENCES}

Bari, M. A., \& Smettem, K. R. J. (2006). A conceptual model of daily water balance following partial clearing from forest to pasture. Hydrology and Earth System Sciences, 10, 321-337.

Bari, M. A., \& Rodgers, S. (2006). Generating a 100-year Daily Runoff Series for the Ord River Catchment Using the LUCICAT Model. Paper presented at the Hydrology and Water Resources Symposium, Hobart, Tasmania.

Bari, M. A., Shakya, D.M., \& Owens, M. (2009). LUCICAT Live - A modelling framework for predicting catchment management options. In Anderssen, R.S., R.D. Braddock and L.T.H. Newham (eds) 18th World IMACS Congress and MODSIM09 International Congress on Modelling and Simulation. Modelling and Simulation Society of Australia and New Zealand and International Association for Mathematics and Computers in Simulation, July2009, pp.3457-3463.ISBN:978-0-9758400-7-8. http://www.mssanz.org.au/modsim09/I8/bari.pdf

Beeton, RJS, Buckley, K. I, Jones, G. J, Morgan, D., Reichelt, R. E, Trewin, D. (2006 Australian State of the Environment Committee). (2006). Australia State of the Environment 2006. Independent report to the Australian Government Minister for the Environment and Heritage, Department of the Environment and Heritage, Canberra.

Charles, S. P., Bari, M. A., Kitsios, A., \& Bates, B. C. (2007). Effect of GCM bias on downscaled precipitation and runoff projections for the Serpentine catchment, Western Australia. International Journal of Climatology, 27(12), 1673-1690. doi: 10.1002/joc.1508

Christensen, N. S., \& Lettenmaier, D. P. (2007). A multimodel ensemble approach to assessment of climate change impacts on the hydrology and water resources of the Colorado River Basin. Journal of Hydrology and Earth System Sciences, 11, 1417-1434.

CSIRO (2009) Water in the Timor Sea Drainage Division. A report to the Australian Government from the CSIRO Northern Australia Sustainable Yields Project. CSIRO Water for a Healthy Country Flagship, Australia. xl $+508 \mathrm{pp}$

IOCI (2002). Climate variability and change in south west Western Australia, Indian Ocean Climate Initiative Panel.

IPCC. (2007). Climate Change 2007: Synthesis Report. In Peter Bosch Lenny Bernstein, Osvaldo Canziani, Zhenlin Chen (Ed.), Fourth Assessment Report (pp. 49): Intergovernmental Panel on Climate Change.

Jones, D. A., Wang, W., \& Fawcett, R. (2009). High-quality spatial climate data-sets for Australia. Australian Meteorological and Oceanographic Journal, 58, 233-248.

Miller, W.A., \& Cunge, J.A. (1975). Simplified equations of unsteady flow. In K. Mahmood \& V. Yevjevich (Eds.), Unsteady Flow in Open Channels (Vol. 1, pp. 183-257). Fort Collins, U.S.A.: Water Resources Publications.

Timbal, B., Fernandez, E., \& Li, Z. (2009). Generalization of a statistical downscaling model to provide local climate change projections for Australia. Environmental Modelling \& Software, 24(3), 341-358. doi: 10.1016/j.envsoft.2008.07.007

Wood, E. F., Lettenmaier, D. P., \& Zartarian, V. G. (1992). A land-surface hydrology parameterization with subgrid variability for general circulation models. J. Geophys. Res., 97(D3), 2717-2728. doi: $10.1029 / 91 \mathrm{jd} 01786$ 